\title{
MENGUKUR INDEKS KERUKUNAN ANTAR UMAT BERAGAMA DI KABUPATEN KONAWE SELATAN
}

\section{Measuring Index of Harmonious Inter Religion Relation in South Konawe}

\author{
Saprillah \\ Balai Penelitian dan Pengembangan Agama Makassar \\ Jl.A.P.Pettarani No.72 Makassar \\ Email: pepi_litbang@yahoo.com
}

Naskah diterima tanggal 6 September 2014. Naskah direvisi tanggal 6 Agustus 2014. Naskah disetujui tanggal 11 Agustus 2014

\begin{abstract}
Abstrak
Penelitian ini merupakan bagian dari penelitian tentang pengukuran Indeks Kerukunan Antar Umat Beragama di Provinsi Sulawesi Tenggara. Penelitian ini bertujuan untuk mengukur tingkat kerukunan antar umat beragama di Kab. Konawe Selatan. Variabel yang menjadi alat ukur ada empat yaitu; hubungan sosial, hubungan keagamaan, nilai dan lokus sosial, dan dukungan pemerintah. Penelitian menggunakan metode kuantitatif dengan jumlah sampel yang disebar sebanyak 138 (dari 1100 sampel di seluruh Provinsi Sulawesi Tenggara). Lokasi penyebaran angket berbasis desa/kelurahan yang memiliki tingkat pluralitas yang tinggi. Temuan penelitian menunjukkan bahwa 1). Indeks kerukunan antar umat beragama di Kab. Konsel berada pada nilai 2,86 atau berada pada tingkat tinggi. Penerimaan dan penghargaan terhadap sesama warga relatif tinggi. Hal ini ditunjukkan dengan sikap terbuka dalam konteks hubungan sosial. Bahkan, responden yang berasal dari kelompok agama minoritas menampakkan keterbukaan dalam hal keagamaan. 2). Faktor agama, usia, dan pengalaman interaksi tampaknya mempengaruhi kualitas kerukunan antar umat beragama. Kelompok agama mayoritas mengalami hambatan dalam hal merayakan pergaulan dalam konteks keagamaan meski secara sosial tidak bermasalah. Kelompok responden yang berusia matang menunjukkan sikap yang lebih terbuka. Begitu pula dengan pengalaman interaksi, semakin tinggi interaksinya maka peluang semakin rukun lebih besar. 3). Faktor adat dan karakter orang Tolaki yang terbuka menjadi salah satu katup pengaman yang penting dalam konteks pembangunan kerukunan. Hukum adat sejauh ini menjadi elemen penting yang dapat menyelesaikan konflik antar individu.
\end{abstract}

Kata kunci: kerukunan, umat beragama, hubungan sosial, nilai dan lokus sosial, peran pemerintah

\begin{abstract}
This study is part of research on the index measurement on religious inter relation in south east Sulawesi and aimed to measure the level of inter religion relationship in South Konawe. There are four variables measured; social relation, religious relation, social locus and value and government support. Research used qualitative method with 138 distributed samples (from 1100 samples from all over South East Province). questionnaire was distributed in location with high pluralistic community. Research shows that 1). the index of interfaith relation in Konawe was 2,86 (high). the degree of acceptance and respect to the fellow citizens was relatively high. They showed open-mindedness to the social relation, especially minority. 2). religion, age, experience influenced the degree of tolerance to others. although socially not a problem, the majority has to adapt to minority in celebrating religious events. Mature aged Respondents showed more open attitude. respondents with greater interaction with those from other religion, showed greater tolerance. 3). Culture and open character of Tolaki people support the interfaith relation between people. customary laws has so far been important element to resolve conflict.
\end{abstract}

Keywords: interfaith relation, social relation, value, locus, government support 


\section{PENDAHULUAN}

$\mathrm{K}$ erukunan merupakan isu yang selalu kontekstual dalam Negara Kesatuan Republik Indonesia, karena lapisan sosial masyarakat-nya sangat beragam baik dari sisi keyakinan maupun etnisitas yang sudah terbentuk sejak pra-kemerdekaan. Migrasi antar penduduk baik melalui jalur kultural (perdagangan) maupun politik (kepentingan antar dua kerajaan) membentuk corak masyarakat nusantara yang beragam jauh sebelum kemederkaan. Kehadiran orang Bugis di Kalimantan Timur misalnya sudah dimulai sejak zaman kerajaan. Kebijakan transmigrasi Orde Baru tahun 1970-1990an semakin menyemarakkan keanekaragaman tersebut. Struktur sosial masyarakat di beberapa daerah khususnya di Kawasan Timur Indonesia, termasuk Provinsi Sulawesi Tenggara perlahanlahan mengalami perubahan. Daerah-daerah yang semula dominan beragama tertentu mau tidak mau harus mulai terbiasa dengan menerima saudara berbeda agama di wilayahnya. Sesekali ada ketegangan. Beberapa wilayah di Papua sempat menolak ide transmigrasi karena menganggap ada agenda Islamisasi yang terselubung di belakangnya (Toni Wanggai, 2009 : 152).

Ancaman terhadap kerukunan memang selalu muncul setiap saat, bahkan semakin menguat pasca reformasi. Sebut saja, kasus Gereja Yasmin dan HKBP di Bogor, Jawa Barat. Kasus penolakan sebagian masyarakat Papua Barat terhadap Masjid Raya Manokwari. Kasus konflik Poso, Ambon, dan Mamasa. Kasus de-legitimasi kelompok Ahmadiyah dan Syiah di beberapa daerah. Beberapa kelompok LSM seperti Setara Institute dan The Wahid Institute menunjukkan adanya kecenderungan anarkisme melalui isu agama menguat di Indonesia, khususnya pascareformasi. ${ }^{1}$ Kehadiran kelompok Islam yang bercorak fundamentalis banyak menginisiasi terjadinya kericuhan sosial itu. Semua ini menunjukkan kalau kerukunan antar dan intra umat beragama selalu terancam oleh berbagai faktor.

Apa yang telah dilakukan oleh negara? Sejak tahun 1965, pemerintah RI telah mengeluarkan PP (Peraturan Pemerintah) No. 1 tahun 1965 tentang pencegahan penodaan dan penyalahgunaan agama. Pada masa ORBA Perpres ini ditetapkan menjadi UU no 5 tahun 1969. Dalam praktiknya, UU ini menimbulkan perdebatan di masyarakat. UU ini oleh sebagian kalangan dijadikan sebagai alat untuk mendelegitimasi kelompok tertentu. Misalnya keberadaan Ahmadiyah di Indonesia digugat berdasarkan UU ini.

Regulasi tentang kerukunan umat beragama ini sebenarnya dapat dilihat mulai dari UUD 1945 sebagai salah satu sumber hukum tertinggi di Indonesia. Hal ini dapat dilihat pada pasal 29, khususnya ayat 2 . Pada pasal 29 ayat 2 itu dinyatakan bahwa negara menjamin kemerdekaan tiap penduduk untuk memeluk agama dan kepercayaan serta meyakini agama dan kepercayaan tersebut. Hal ini menunjukkan adanya kebebasan beragama di indonesia sesuai dengan nurani tiap orang. Namun yang terpenting dari kebebasan itu, adalah tanggung jawab dan kemauan untuk saling menjaga dan memberi ruang bagi kebebasan yang lain. Inilah yang menjadi dasar dari kerukunan tersebut.

Selanjutnya beberapa regulasi yang dianggap terkait dengan kerukunan beragama adalah UU No 1/PNPS/1965 tentang larangan penodaan dan penyalahgunaan agama. Keputusan bersama Menteri Agama dan Menteri Dalam Negeri No 1 /Ber/Mdn/1965 tentang pelaksanaan oleh Pemerintah Daerah tentang jaminan pemeluk agama melaksanakan ajaran agamanya. SK Menteri Agama dan Menteri Dalam Negeri no.1/1979 tentang tata cara penyiaran agama dan aturan bantuan luar negeri terhadap lembaga swasta untuk kegiatan keagamaan. Surat edaran Menteri Agama RI tentang penyelenggaraan hari raya No.MA/432.1981. Paling anyar adalah Peraturan Bersama Menteri (PBM) antara Menteri Dalam Negeri dan Menteri Agama Nomor 8 dan Nomor 9 tahun 2006.

Selain itu salah satu regulasi yang terkait dengan kebebasan beragama adalah UU 39/1999. UU ini muncul setelah Indonesia meratifikasi aturan HAM. Khusus yang terkait dengan agama adalah pasal 22 yang mengandung makna bahwa setiap warga Negara Indoensia dijamin oleh Negara untuk memeluk agama dan keyakinan tertentu. Pasal ini sendiri semakna dengan UUD 45 pasal 29.

Peran pemerintah memang sangat dibutuhkan dalam merawat dan menjaga rakyat agar tidak terjatuh dalam konflik. Peran itu tidak harus selalu berujung pada pembuatan regulasi yang sifatnya multitafsir. Peran itu bisa dilakukan dengan mendorong masyarakat secara mandiri menjaga kerukunan. Tetapi di lain pihak, negara tidak bisa membangun semangat 'pembatasan' kreatifitas 
beragama. Itulah sebabnya prolegnas tentang UU Kerukunan masih terus mendapat kritik tajam dari publik (Editorial Media Indonesia. 2014).

Kerukunan bagi orang Indonesia adalah keniscayaan. Kerukunan beragama berarti hubungan sesama umat beragama dilandasi toleransi, saling pengertian, saling menghormati, menghargai kesetaraan dalam pengamalan ajaran agamanya dan kerjasama dalam kehidupan bermasyarakat, berbangsa dan bernegara di dalam Negara Kesatuan Republik Indonesia berdasarkan Pancasila dan UUD RI tahun (Hamdan, 2008). Masyarakat Indonesia telah memiliki pengalaman panjang tentang merawat kerukunan (Hamdan, 2008). Masyarakat Indonesia pun memiliki mekanisme kultural untuk mendamaikan keragaman dan perbedaan etnik atau agama yang sakral sekalipun. Ia lazim disebut kearifan lokal, local wisdom, sebuah kebijaksanaan yang ditransmisikan dari satu generasi ke generasi berikutnya. Selain itu, kelompok yang menginginkan perdamaian dan kerukunan juga muncul dimana-mana. Baik dalam bentuk organisasi sosial maupun individu seperti Gus Dur, Johan Efendi, Cak Nur dan tokoh lainnya. Artinya, kalau pun ada konflik atau kekerasan yang terjadi bersamaan dengan itu muncul pula inisiasi perdamaian baik dalam konteks perseorangan maupun kelompok. Itulah dinamika keagamaan di Indonesia.

Penelitian Kerukunan Umat Beragama di Sulawesi Tenggara tidak banyak dilakukan. Boleh dikatakan tidak ada kajian populer tentang ini di Sulawesi Tenggara. Mengapa? Karena penelitian tentang kerukunan biasanya lebih banyak dikaitkan dengan situasi yang khas. Situasi yang khas dimaksud adalah adanya konflik di wilayah tersebut atau ada citra tertentu yang berkaitan dengan kerukunan. Tidak mengherankan kalau kajian serupa ini mudah ditemukan di Sulawesi Barat pasca konflik di Mamasa. Misalnya, disertasi Idham (2011) tentang Konflik ATM. Disertasi ini tidak hanya menceritakan tentang konflik ATM tetapi juga mekanisme penyelesaian konflik yang menggunakan cara kultural. Penelitian ini pun mudah ditemukan di Sulawesi Utara yang memiliki citra sebagai wilayah yang rukun. Misalnya tulisan Anita Deka (2008) yang berjudul Manado, Monumen Pluralisme Agama. Tulisan ini mengonfirmasi citra Manado sebagai wilayah yang rukun. Termasuk penelitian Tim Kehidupan Balai Litbang (2008) tentang jarak sosial antar komunitas Islam dan Kristen di Kota Manado. Tentu saja, tidak boleh dilupakan penelitian serial potret kerukunan antar umat beragama di enam provinsi di Kawasan Timur Indonesia (Laporan penelitian Balitbang Agama Makassar: 2009-2013).

\section{Tinjauan Pustaka \\ Meminjam Teori Walzer dan Diana L Eck; Toleransi Aktif = Pluralisme}

Penelitian ini adalah penelitian serial. Dalam lima tahun terakhir Balai Litbang Agama Makassar melakukan penelitian di enam provinsi yang berbeda yaitu Sulawesi Selatan (2009), Sulawesi Tengah (2010), Sulawesi Utara (2011), Kalimantan Timur (2012), Sulawesi Barat dan Gorontalo (2013), dan untuk tahun 2014 dilakukan di Provinsi Sulawesi Tenggara. Tujuannya adalah mengukur indeks kerukunan antar umat beragama di wilayah penelitian dan memetakan faktor-faktor yang mempengaruhi tingkat kerukunan tersebut. Faktor yang dimaksud tidak sekadar pada realitas yang dikonstruksi dalam angket tetapi juga faktor sosial, budaya, dan lainnya yang dalam perspektif peneliti ikut menyumbang tingkat kerukunan pada masyarakat Sulawesi Tenggara.

Pengukuran indeks kerukunan umat beragama ini bermanfaat sebagai bentuk counter terhadap pencitraan Indonesia yang buruk dalam hal kerukunan antar umat beragama. Hasil penelitian serupa di enam provinsi menunjukkan tingkat Kerukunan Antar Umat Beragama berada pada level yang tinggi (Laporan Penelitian Tim Kehidupan Beragama, 2009-2013). Artinya, kerukunan antar umat beragama berlangsung dengan baik. Masyarakat telah memiliki cara tersendiri untuk "berinteraksi" dengan kelompok sosial yang berbeda identitas. Hasil penelitian ini bisa memberikan argumen bahwa konflik sosial yang terjadi di Indonesia, apa pun bentuknya, bukan terjadi secara natural tetapi "rekayasa sosial" dari kelompok tertentu dengan motif dan kepentingan yang tertentu pula. Mengapa? Karena masyarakat Indonesia memiliki mekanisme kultural dalam merawat kerukunan.

Untuk mendapatkan perspektif yang cocok melihat realitas di atas, penelitian ini menjatuhkan pilihan pada teori toleransi aktif-nya Walzer atau pluralisme Diana L. Eck. Mengapa toleransi aktif? Ada baiknya kita merenungi sejenak tulisan Trisno (2010) yang berjudul "Melampui Toleransi" merefleksi konsep toleransi Walzer berikut ini:

Walzer mengingatkan dua bentuk praktik toleransi yang berkembang dalam sistem negara- 
bangsa, yakni asimilasi individu dan pengakuan hak-hak kelompok, pada dasarnya merupakan proyek utama politik demokrasi modern. Di situ toleransi dilandaskan pada hak-hak individu sebagai warga tanpa memandang keanggotaannya dalam suatu kelompok primordial. Dengan itu, proyek modernis yang mau memasukkan semua orang ke dalam sistem demokrasi (the politics of inclusion, memakai istilah Habermas) dapat berlangsung. Namun, Walzer mengingatkan bahwa proyek ini berwajah ganda: pada satu pihak ada pergulatan untuk masuk menjadi warga yang setara, pada pihak lain-karena tuntutan hak-hak kelompok, khususnya kelompok minoritas, untuk bersuara, memperoleh tempat, dan menjalankan politiknyadapat juga berarti pemisahan.

Saya tidak ingin memasuki persoalan itu secara rinci di sini. Namun, setidaknya tuturan di atas memperlihatkan bahwa konsep toleransi itu sendiri tidaklah memadai untuk menangani kompleksitas persoalan yang ada. Seorang pemikir Kristen Koptik dari Mesir, Milad Hanna (2005), mengingatkan bahwa toleransi, yang sering diterjemahkan ke dalam bahasa Arab sebagai altasâmuh, selalu mengandaikan relasi kuasa yang tidak seimbang sebagai konteksnya. (Ingat diktum di atas: bahwa the language of tolerance is the language of power) Karena itu, ia mengusulkan istilah baru, qabûlul âkhar, 'menyongsong sang liyan', yang lebih aktif dan egaliter sebagai bahasa baru toleransi. Kata Hanna, "Kata al-tasâmuh hanya bermakna ketika ada suatu pihak bersalah, lalu pihak lain menenggang rasa. Sedangkan qabûlul âkhar bermakna lebih dalam dan lebih aktif: menerima dan menyongsong orang lain, tidak sekadar bertenggang rasa." Namun, dengan itu pula, kita sudah menyeberangi batas-batas yang didirikan Michael Walzer dan merambah ranah problematis baru yang harus kita bicarakan dan arungi bersama.

Tulisan di atas memberi gagasan tentang pentingnya bergerak dari titik toleransi (pasif). Menggugah kita untuk menyadari kalau toleransi (pasif) adalah bahasa kekuasaan yang sudah tidak memadai lagi digunakan dalam konteks sosial yang lebih komprehensif seperti sekarang. Ia -mengutip Milad Hanna- mengusulkan istilah "menyongsong sang liyan" atau qabulul akhar (menerima yang lain) sebagai bahasa baru dari toleransi yang lebih aktif. Toleransi bukan lagi sekedar tenggang rasa tetapi aktif memberi rasa. Istilah ini bisa disederhanakan dengan menggunakan istilah toleransi aktif.
Konsep toleransi (aktif) Walzer (1997) mencakup lima hal yaitu 1.) Menerima perbedaan untuk hidup damai, 2.) menjadikan keseragaman menjadi perbedaan, 3.) menerima bahwa orang lain memiliki hak, 4.) mengekspresikan keterbukaan terhadap orang lain, ingin tahu, menghargai, ingin mendengarkan dan belajar dari yang lain, 5.) dukungan yang penuh terhadap perbedaan dan menekankan aspek otonomi.

Toleransi aktif yang dimaksud dalam penelitian ini sesungguhnya adalah pluralisme. Diana L. Eck (2003) menyebutkan ada lima ciri khas pluralisme, yaitu: pertama, pluralisme berbeda dengan pluralitas. Ia adalah "theenergeticengagement with diversity", pergumulan yang energik (aktif) terhadap kepelbagaian. Kedua, pluralisme bukan (sekadar) toleransi, melainkan proses active seeking of understanding across line of difference, pencarian pemahaman yang aktif terhadap perbedaan. Ketiga, pluralisme bukan relativis melainkan the encounter of commitment (pergumulan komitmen). Keempat, pluralisme berbeda dengan sinkretisme. Pluralisme mengandaikan saling menghormati di atas basis saling menghargai perbedaan dan keunikan masingmasing tradisi agama. Kelima, pluralisme dibangun berdasarkan dialog (antar iman).

Inti dari paradigma Diana L Eck adalah pergumulan yang aktif dari berbagai kelompok sosial untuk saling mempelajari, saling mengetahui fondasi ajaran agama bukan untuk saling menyalahkan atau saling menyerang tetapi untuk saling menghargai perbedaan. Pluralisme bukan ajaran peleburan agama, penyamaan agama, atau nihilisme agama. Perbedaan agama menjadi sumber energi untuk membangun kebersamaan. Konsep ini penting untuk menjernihkan kekeliruan beberapa pihak yang kontra-pluralisme, dengan menganggap pluralisme adalah ajaran yang menyamakan semua agama (bandingkan dengan Sumanto Al-Qurtubi, 2009).

Penelitian ini tidak membedakan antara paradigma toleransi aktif dan pluralisme. Toleransi aktif ala Walzer adalah pluralisme ala Diana L. Eck. Walzer menginginkan bahwa perbedaan menjadi pijakan untuk kehidupan yang lebih damai. Kelompok sosial bergerak aktif untuk saling mempelajari satu sama lain. Ini yang disebut oleh Diana L. Eck sebagai pergumulan yang aktif. Bedanya, Walzer berangkat dari kesediaan menerima perbedaan yang merupakan ciri khas konsep toleransi sedangkan Diana L Eck berangkat 
dari keaktifan bergerak dalam perbedaan. Asumsinya, tidak satu pun orang yang tidak menerima kepelbagian sebagai sesuatu yang given, sunnatullah. Bersedia atau tidak, manusia global harus hidup dalam perbedaan identitas, tetapi tidak banyak yang bersedia untuk saling mempelajari satu sama lain untuk kepentingan perdamaian.

\section{METODE PENELITIAN}

Penelitian ini sejatinya penelitian tim, bukan individual. Lokasi utamanya adalah Provinsi Sulawesi Tenggara. Dengan demikian populasinya adalah seluruh warga Sultra yang berjumlah 2,232,586. Jumlah sampel ditentukan dengan menggunakan rumus Slovin, $(n=\mathrm{N} / 1+\mathrm{N}$. $\mathrm{d}^{2}$ ) dengan galat dugaan 0,03 atau dengan kata lain tingkat kepercayaan mencapai derajat $97 \%$. Dengan hitungan itu ditemukan jumlah sampel sebesar 1.100. Seluruh sampel ini disebar ke 10 Kabupaten/ Kota yang menjadi sampel lokasi. Berdasarkan sebaran angket di atas, jumlah sampel untuk wilayah Kab. Konsel adalah 138 orang. Sampel ini disebar ke responden dengan perimbangan $70 \%$ angket untuk responden beragama Islam, 30\% lainnya disebar ke agama yang ada dengan mempertimbangkan aspek kuantitas masing-masing agama (lihat identitas responden). Sampel individu dipilih secara acak.

Sedangkan penetapan lokasi penyebaran angket ditetapkan berbasis Kecamatan dengan melihat pluralitas penduduknya. Berdasarkan itu, kami memilih Kecamatan Ranomeeto dengan mengambil Desa Langgea dan Desa Kota Bangun sebagai lokasi penyebaran angket. Pemilihan dua desa ini pun menggunakan realitas pluralitas penduduk sebagai alasannya. Pengolahan dan analisis data dilakukan dengan menetapkan indeks yang dijadikan sebagai landasan pengukuran tingkat kerukunan antar umat beragama. Indeks ditetapkan dengan menggunakan rumus:

Nilai Total

Responden $\mathrm{x}$ jumlah pertanyaan

Dari rumus di atas ditetapkan indeks kerukunan sebagai berikut:

$$
\begin{array}{ll}
1-1,75 & =\text { sangat rendah } \\
1,76-2,5 & =\text { rendah } \\
2,6-3,25 & =\text { tinggi } \\
3,26-4 & =\text { sangat tinggi. }
\end{array}
$$

\section{PEMBAHASAN \\ Indeks Kerukunan Antar Umat Beragama di Konsel}

Tabel 1. Indeks kerukunan berdasarkan variabel yang diukur

\begin{tabular}{cccc}
\hline No & Variabel & Indeks & Kategori \\
\hline 1 & Hubungan Sosial & 2,98 & Tinggi \\
2 & Hubungan keagamaan & 2,38 & Rendah \\
3 & Nilai dan Lokus Sosial & 3,1 & Tinggi \\
4 & Peran Pemerintah & 3,1 & Tinggi \\
& Indeks Keseluruhan & 2,86 & Tinggi \\
\hline
\end{tabular}

Sumber data: Angket yang diolah

Data pada tabel di atas menunjukkan bahwa indeks keseluruhan dari empat variabel yang diukur memperoleh nilai 2,86 atau berada pada kategori tinggi. Artinya, kerukunan antar umat beragama di Konsel sudah baik sebagaimana yang telah menjadi angan sosial bersama. Dua variabel yang mendapatkan respon paling tinggi adalah variabel 3 dan 4 (Nilai dan lokus sosial, dan peran pemerintah). Ini berarti ada kepercayaan yang tinggi dari masyarakat terhadap nilai, lokus sosial, dan pemerintah daerah dalam membangun kerukunan umat beragama di wilayah mereka. Variabel 2 menjadi penyumbang nilai indeks paling rendah. Variabel ini menunjukkan kesediaan responden untuk berhubungan secara keagamaan terlihat rendah.

\section{Indeks KUB berdasarkan variabel A (hubungan sosial)}

Tabel 2. Indeks KUB berdasarkan subvariabel pada variabel hubungan sosial

\begin{tabular}{clcc}
\hline No & \multicolumn{1}{c}{ Subvariabel } & Indeks & Kategori \\
\hline 1 & Bersedia Berteman & 3,10 & \\
2 & Bersedia mengundang & 2,94 & \\
3 & Bersedia menghadiri & 2,85 & \\
& undangan & & Tinggi \\
4 & Bersedia bertetangga & 3,13 & \\
5 & Bersedia memberi bantuan & 3,17 & \\
6 & Bersedia berjual beli & 3,12 & \\
7 & Bersedia satu organisasi & 2,90 & \\
8 & Bersedia dipimpin orang beda & 2,72 & \\
& agama & & \\
9 & Bersedia mendengar saran & 2,87 & \\
& tokoh agama lain & 2,98 & \\
& Indeks &
\end{tabular}


Nilai indeks pada tabel di atas berada pada angka 2,98 atau berada pada kategori tinggi. Artinya, hubungan sosial antar umat beragama di Konsel berjalan dengan baik. Ini berkesesuaian dengan asumsi tentang "sikap rukun" yang dipercayai oleh sebagian besar masyarakat Konsel.

Nilai indeks ini menunjukkan bahwa mayoritas responden memberikan respon positif terhadap seluruh pertanyaan yang diajukan. Tidak satu pun sub-variabel pada variabel hubungan sosial ini mendapatkan nilai ambang bawah rendah $(2,5)$ tetapi juga tidak sampai nilai indeks ambang atas $(3,25)$. Nilai indeks variabel hubungan sosial ini berada pada level tengah cenderung ke atas. Lebih tinggi 0,48 poin dari nilai ambang bawah dan lebih rendah 0,27 dari ambang batas atas. Jika data indeks ini diubah dalam bentuk persentasi, maka kita mendapatkan jumlah responden yang memiliki kecenderungan terbuka terhadap perbedaan dalam konteks hubungan sosial sebanyak 89,1\% (12,3\% diantaranya sangat terbuka).

Ini menunjukkan kesediaan untuk membangun relasi sosial antar kelompok agama yang ada sudah signifikan untuk disebut rukun. Jumlah yang bersedia berteman, bersedia menghadiri undangan, bersedia mengundang, bersedia bertetangga dan lain-lain lebih banyak dari yang tidak (atau kurang) bersedia.

Bagaimana kecenderungan peta kelompok responden yang memiliki kecenderungan terbuka tersebut. Perhatikan tabel crosstabulasi berikut ini:

Tabel 3. crosstab Agama dan Hubungan Sosial

\begin{tabular}{cccccc}
\hline Agama & \multicolumn{3}{c}{ Hubungan Sosial } & & Total \\
& $\begin{array}{c}\text { Sangat } \\
\text { Rendah }\end{array}$ & Rendah & Tinggi & $\begin{array}{c}\text { Sangat } \\
\text { Tinggi }\end{array}$ & \\
\hline Islam & 1 & 14 & 73 & 7 & 95 \\
Kristen & 0 & 0 & 9 & 3 & 12 \\
Katolik & 0 & 0 & 1 & 2 & 3 \\
Hindu & 0 & 0 & 23 & 5 & 28 \\
Total & 1 & 14 & 106 & 17 & 138 \\
\hline
\end{tabular}

Data di atas menunjukkan ada 15 (15,8\% dari 95) responden beragama Islam yang memiliki persepsi yang tertutup terhadap pergaulan antar agama berbasis sosial (bahkan ada satu orang responden yang sangat tertutup). Sedangkan dari kelompok agama lain seluruhnya berada pada persepsi yang relatif terbuka.
Tabel 4.Crosstabulasi Pengalaman Interaksi dan Hubungan Sosial

\begin{tabular}{cccccc}
\hline $\begin{array}{c}\text { Pengalaman } \\
\text { Interaksi }\end{array}$ & $\begin{array}{c}\text { Sangat } \\
\text { Rendah }\end{array}$ & Rendah & Tinggi & $\begin{array}{c}\text { Sangat } \\
\text { Tinggi }\end{array}$ & Total \\
\hline Sangat rendah & 0 & 1 & 3 & 0 & 4 \\
Rendah & 1 & 6 & 15 & 0 & 22 \\
Tinggi & 0 & 4 & 62 & 3 & 69 \\
Sangat Tinggi & 0 & 3 & 26 & 14 & 43 \\
Total & 1 & 14 & 106 & 17 & 138 \\
\hline
\end{tabular}

Tabel 4 di atas menunjukkan bahwa kelompok responden yang memiliki pengalaman interaksi yang rendah berpeluang lebih besar untuk memiliki sikap tidak terbuka terhadap pergaulan sosial. 8 (30,8\%) dari 26 responden berpengalaman rendah dan sangat rendah berada pada indeks yang rendah/sangat rendah pula. Sedangkan responden yang berada pada kategori tinggi dan sangat tinggi pengalaman interaksi hanya sekitar 6,2\% (7 dari 112 responden). Ini berarti pengalaman interaksi berimplikasi pada persepsi responden untuk membuka diri pada pergaulan sosial. Semakin tinggi tingkat interaksinya akan semakin terbuka pada penerimaan secara sosial.

\section{Indeks KUB berdasarkan variabel kedua (hubungan keagamaan)}

Tabel 5.Indeks kerukunan berdasarkan subvariabel pada variabel kedua (hubungan keagamaan)

\begin{tabular}{clcc}
\hline No & \multicolumn{1}{c}{ Subvariabel } & Indeks & Kategori \\
\hline 1 & $\begin{array}{l}\text { Bersedia mengundang agama } \\
\text { lain ke acara keagamaan saya }\end{array}$ & 2,21 & Rendah \\
2 & $\begin{array}{l}\text { Bersedia menghadiri acara } \\
\text { keagamaan agama lain }\end{array}$ & 2,15 & Rendah \\
3 & $\begin{array}{l}\text { Bersedia ikut aktif dalam acara } \\
\text { keagamaan orang lain }\end{array}$ & 1,83 & rendah \\
4 & $\begin{array}{l}\text { Bersedia memberi bantuan dana } \\
\text { kepada kegiatan agama lain }\end{array}$ & 2,28 & Rendah \\
5 & $\begin{array}{l}\text { Bersedia membantu } \\
\text { pembangunan rumah ibadah } \\
\text { agama lain }\end{array}$ & 2,22 & Rendah \\
6 & $\begin{array}{l}\text { Tidak keberatan jika ada } \\
\text { penganut agama lain mendirikan } \\
\text { rumah ibadah di lingkungan } \\
\text { saya }\end{array}$ & Tinggi \\
7 & $\begin{array}{l}\text { Tidak keberatan dengan } \\
\text { kegiatan agama lain di sekitar } \\
\text { lingkungan saya }\end{array}$ & Tinggi \\
\hline
\end{tabular}




\begin{tabular}{clcc}
\hline 8 & $\begin{array}{l}\text { Bersedia berdialog dan } \\
\text { musyawarah dengan orang } \\
\text { berbeda agama }\end{array}$ & 2,85 & Tinggi \\
9 & $\begin{array}{l}\text { Bersedia ikut dalam kegiatan } \\
\text { doa bersama dengan agama lain } \\
\text { Indeks Keseluruhan }\end{array}$ & 2,22 & Rendah \\
\hline Sumber data: angket yang diolah & 2,38 & Rendah \\
\hline
\end{tabular}

Sumber data: angket yang diolah

Data pada tabel ini menunjukkan bahwa secara umum nilai indeks untuk variabel B (hubungan keagamaan) berada pada angka 2,38 atau kategori rendah. Meski rendah, namun posisi angka ini lebih dekat ke indeks tinggi $(2,6-3,25)$. Lebih tinggi 0,62 poin dari nilai ambang batas bawah $(1,76)$ dan lebih rendah 0,12 poin dari nilai ambang batas atas $(2,5)$. Ada tiga sub variabel yang memberi sumbangan tinggi pada variabel ini yaitu sub variabel 6 tidak keberatan jika ada penganut agama lain mendirikan rumah ibadah di lingkungan saya, sub variabel 7 tidak keberatan dengan kegiatan agama lain, dan sub variabel 8 bersedia berdialog dan musyawarah dengan orang berbeda agama. Ketiga sub variabel mendapatkan nilai tinggi (lihat tabel) Sedangkan sub-variabel lainnya menunjukkan nilai rendah, bahkan sub variabel 2 bersedia ikut aktif dalam acara keagamaan orang lain, mendapatkan nilai yang mendekati level sangat rendah; 1,83.

Bagaimana peta responden pada variabel $B$ ini? Perhatikan tabel-tabel berikut ini:

Tabel 7 : Crosstabulasi Agama dan Hubungan Keagamaan

\begin{tabular}{|c|c|c|c|c|c|}
\hline \multirow[t]{2}{*}{ Agama } & \multicolumn{4}{|c|}{ Hubungan Keagamaan } & \multirow[t]{2}{*}{ Total } \\
\hline & $\begin{array}{l}\text { Sangat } \\
\text { Rendah }\end{array}$ & Rendah & Tinggi & $\begin{array}{l}\text { Sangat } \\
\text { Tinggi }\end{array}$ & \\
\hline Islam & 16 & 61 & 18 & 0 & 95 \\
\hline Kristen & 0 & 3 & 8 & 1 & 12 \\
\hline Katolik & 0 & 0 & 1 & 2 & 3 \\
\hline Hindu & 0 & 1 & 26 & 1 & 28 \\
\hline Total & 16 & 65 & 53 & 4 & 138 \\
\hline
\end{tabular}

Data pada tabel di atas menunjukkan bahwa seluruh responden yang berada pada nilai indeks sangat rendah berasal dari kelompok responden beragama Islam dan sebagian besar berada pada nilai indeks rendah. Data menunjukkan 77 (81\%) dari 95 orang responden beragama Islam berada pada level indeks rendah dan sangat rendah. Sedangkan, responden yang beragama non Islam mayoritas berada pada kategori indeks tinggi dan sangat tinggi. Hanya $4(9,3 \%)$ dari 43 responden non Islam yang berada pada nilai indeks rendah (tidak ada yang berada di level indeks sangat rendah).

Tabel 8: Crosstabulasi Usia dan Hubungan Keagamaan

\begin{tabular}{cccccc}
\hline ' Usia & \multicolumn{4}{c}{ Hubungan Keagamaan } & Total \\
& $\begin{array}{c}\text { Sgt } \\
\text { Rendah }\end{array}$ & Rendah & Tinggi & $\begin{array}{c}\text { Sgt } \\
\text { Tinggi }\end{array}$ \\
\hline$<40$ tahun & 11 & 45 & 28 & 20 & 86 \\
$41-50$ & 3 & 14 & 10 & 1 & 28 \\
51- keatas & 1 & 6 & 15 & 1 & 23 \\
Tidak jawab & 1 & 0 & 0 & 0 & 1 \\
\hline
\end{tabular}

Tabel ini menunjukkan bahwa distribusi responden yang mendapatkan indeks rendah dan sangat rendah ada di semua level usia. Dengan kecenderungan lebih banyak pada usia di bawah 40 tahun. $56(65,1 \%)$ dari 86 responden usia $<40$ tahun berada pada level indeks rendah dan sangat rendah. $17(60 \%)$ dari 28 responden yang berusia antara 41-50 tahun juga berada di level yang sama. $7(30,4 \%)$ dari 23 yang berusia 51 tahun keatas yang berada di level yang sama. Kecenderungan data menunjukkan semakin dewasa responden jumlah yang berada pada nilai indeks rendah dan sangat rendah semakin berkurang.

Tabel 9: Crosstabulasi Suku dan Hubungan Keagamaan.

\begin{tabular}{cccccc}
\hline Suku & \multicolumn{4}{c}{ Hubungan Keagamaan } & Total \\
& $\begin{array}{c}\text { Sangat } \\
\text { Rendah }\end{array}$ & Rendah & Tinggi & $\begin{array}{c}\text { Sangat } \\
\text { Tinggi }\end{array}$ \\
\hline Tolaki & 1 & 11 & 6 & 0 & 18 \\
Jawa & 7 & 34 & 14 & 1 & 56 \\
Buton/Muna & 3 & 4 & 0 & 0 & 7 \\
Bugis/Mks & 3 & 10 & 5 & 0 & 18 \\
Bali & 0 & 1 & 26 & 1 & 28 \\
Tidak Jawab & 2 & 5 & 2 & 2 & 11 \\
\hline
\end{tabular}

Data pada tabel di atas menunjukkan bahwa responden yang berada pada level indeks rendah dan sangat rendah ada di semua kategori suku (kecuali Bali yang tidak ada yang berada di level indeks sangat rendah). Suku-suku yang selama ini terassosiasi dengan identitas keislaman memiliki kecenderungan yang relatif sama. Responden yang berada di level indeks rendah dan sangat rendah lebih banyak dibandingkan dengan yang berada pada level tinggi. 
Tabel 10: Crosstabulasi Pendidikan dan Hubungan Keagamaan

\begin{tabular}{cccccc}
\hline Pendidikan & \multicolumn{4}{c}{ Hubungan Keagamaan } & Total \\
& $\begin{array}{c}\text { Sangat } \\
\text { Rendah }\end{array}$ & Rendah & Tinggi & $\begin{array}{c}\text { Sangat } \\
\text { Tinggi }\end{array}$ \\
\hline Tidak jawab & 0 & 1 & 0 & 0 & 1 \\
SD & 0 & 8 & 14 & 1 & 23 \\
SMP & 3 & 13 & 6 & 1 & 23 \\
SMA & 9 & 37 & 25 & 0 & 71 \\
S1 & 3 & 6 & 8 & 2 & 19 \\
S2 & 1 & 0 & 0 & 0 & 1 \\
\hline Sumber data: Angket yang diolah & & &
\end{tabular}

Data pada tabel menunjukkan bahwa persebaran responden disemua level indeks menunjukkan kecenderungan yang sama. Semua jenjang pendidikan menyumbang responden yang bernilai indeks sangat, rendah, tinggi. Yang menarik, level pendidikan tampaknya tidak cukup berpengaruh terhadap persepsi responden. Satusatunya responden yang berjenjang S2 justru menunjukkan sikap yang tertutup. Begitu pula pada jenjang S1, ada $9(47,4 \%)$ dari 19 responden yang menunjukkan sikap tertutup. Tentu saja ini tidak bisa dipahami secara general karena keterbatasan responden yang terjaring.

Tabel 11: Crosstabulasi Pekerjaan dan Hubungan Keagamaan

\begin{tabular}{cccccc}
\hline Pekerjaan & \multicolumn{4}{c}{ Hubungan Keagamaan } & Total \\
& $\begin{array}{c}\text { Sangat } \\
\text { Rendah }\end{array}$ & Rendah & Tinggi & $\begin{array}{c}\text { Sangat } \\
\text { Tinggi }\end{array}$ & \\
\hline PNS & 1 & 0 & 5 & 0 & 6 \\
Wiraswasta & 4 & 21 & 16 & 1 & 42 \\
IRT & 8 & 16 & 7 & 1 & 32 \\
Pensiunan & 0 & 2 & 2 & 0 & 4 \\
Pelajar/Mhs & 2 & 9 & 3 & 0 & 14 \\
Petani & 0 & 4 & 13 & 0 & 17 \\
Tidak & 1 & 13 & 7 & 1 & 22 \\
Jawab & & & & & \\
\hline Sumber data: Angket yang diolah & & &
\end{tabular}

Seperti kecenderungan kategori yang lain, persebaran responden hampir terjadi disemua level indeks. Semua jenis pekerjaan menyumbang responden untuk level indeks sangat rendah, rendah, dan tinggi. Untuk jenis pekerjaan wiraswasta, IRT, dan pelajar/mahasiswa, jumlah responden yang berada pada level indeks rendah dan sangat rendah lebih banyak ketimbang level sebaliknya.
Tabel 12: Crosstab Pengalaman Interaksi dan Hubungan Keagamaan

\begin{tabular}{cccccc}
\hline $\begin{array}{c}\text { Pengalaman } \\
\text { Interaksi }\end{array}$ & \multicolumn{4}{c}{ Hubungan Keagamaan } & Total \\
& $\begin{array}{c}\text { Sangat } \\
\text { Rendah }\end{array}$ & Rendah & Tinggi & $\begin{array}{c}\text { Sangat } \\
\text { Tinggi }\end{array}$ \\
\hline Sngt rendah & 2 & 2 & 0 & 0 & 4 \\
Rendah & 6 & 14 & 2 & 0 & 22 \\
Tinggi & 6 & 32 & 31 & 0 & 69 \\
Sangat Tinggi & 2 & 17 & 20 & 4 & 43 \\
\hline
\end{tabular}

Data yang terlihat pada tabel ini menunjukkan kecenderungan pada variabel A. Mayoritas responden yang rendah dan sangat rendah pengalaman interaksinya memiliki pandangan keagamaan yang tertutup. 20 (90,9\%) dari 22 responden tersebut berada pada level indeks rendah dan sangat rendah. Tetapi, responden yang memiliki pengalaman interaksi tinggi pun menunjukkan kecenderungan serupa. 54 (48.2\%) dari 112 responden kelompok ini berada pada indeks yang rendah dan sangat rendah.

Kecenderungan tabulasi data di atas secara keseluruhan menunjukkan ada beberapa variabel identitas responden yang berpengaruh pada indeks variabel kedua ini dan ada beberapa variabel yang tidak berpengaruh. Untuk melihat pengaruh, ada baiknya memerhatikan analisis corelasi antara identitas responden dan variabel kedua, sebagai berikut:

Tabel 13: Analisis corelasi antara variabel

\begin{tabular}{cccc}
\hline No & Identitas Responden & Sig. & Keterangan \\
\hline 1 & Jenis kelamin & 0,19 & Tidak berkorelasi \\
2 & Agama & 0,00 & Berkorelasi \\
3 & Suku & 0,00 & Berkorelasi \\
4 & Usia & 0,03 & Berkorelasi \\
5 & Pendidikan & 0,22 & Tidak Berkorelasi \\
6 & Pekerjaan & 0,93 & Tidak berkorelasi \\
7 & Pengalaman & 0,00 & Berkorelasi \\
& interaksi & & \\
\hline
\end{tabular}

Ket: Signifikansi korelasi $<0,05$

Analisis corelasi ini menguatkan peta crostabulasi di atas bahwa jenis kelamin, pendidikan, pekerjaan tidak berhubungan dengan cara pandang terhadap hubungan keagamaan. Yang memiliki hubungan adalah agama, suku, usia, dan pengalaman interaksi. Artinya agama bisa 
mempengaruhi cara pandang terhadap kerukunan, suku bisa mempengaruhi, usia dan pengalaman interaksi juga bisa mempengaruhi peta kerukunan.

C.4. Indeks KUB berdasarkan variabel ketiga (nilai dan lokus sosial)

Tabel 4; Indeks kerukunan berdasarkan subvariabel pada variabel ketiga

\begin{tabular}{|c|c|c|c|}
\hline No & Subvariabel & Indeks & Kategori \\
\hline 1 & $\begin{array}{l}\text { Agama saya mengajarkan untuk } \\
\text { bergaul dan menghormati } \\
\text { penganut agama lain }\end{array}$ & 3,44 & $\begin{array}{l}\text { Sangat } \\
\text { tinggi }\end{array}$ \\
\hline 2 & $\begin{array}{l}\text { Pembangunan rumah ibadah } \\
\text { harus dimusyawarahkan dengan } \\
\text { semua unsur agama yang ada }\end{array}$ & 3,01 & Tinggi \\
\hline 3 & $\begin{array}{l}\text { Peran tokoh agama sangat penting } \\
\text { dalam memelihara KUB }\end{array}$ & 3,30 & $\begin{array}{c}\text { Sangat } \\
\text { tinggi }\end{array}$ \\
\hline 4 & $\begin{array}{l}\text { Peran tokoh adat dan etnik sangat } \\
\text { penting dalam memelihara KUB }\end{array}$ & 3,19 & Tinggi \\
\hline 5 & $\begin{array}{l}\text { Kegiatan adat bisa membangun } \\
\text { kerukunan antar umat beragama }\end{array}$ & 2,98 & Tinggi \\
\hline 6 & $\begin{array}{c}\text { Saling menghormati antar } \\
\text { pemeluk agama sesuai dengan } \\
\text { budaya masyarakat Sultra }\end{array}$ & 3,20 & Tinggi \\
\hline 7 & $\begin{array}{l}\text { Organisasi agama boleh } \\
\text { membantu perayaan hari-hari } \\
\text { besar agama lain }\end{array}$ & 2,59 & Rendah \\
\hline & Indeks Kerukunan & 3,10 & Tinggi \\
\hline
\end{tabular}

Sumber data: angket yang diolah

Data pada tabel menunjukkan bahwa seluruh sub-variabel dalam variabel ketiga ini mendapatkan respon baik. Seluruhnya berada pada level indeks baik. Sub-variabel 1 dan 3 mendapatkan nilai indeks yang sangat tinggi (lihat tabel). Subvariabel 1 bersifat nilai. Seluruh responden percaya bahwa agama mereka sangat mengajarkan untuk pergaulan dan penghormatan terhadap agama lain. Tentu saja yang dimaksud adalah pergaulan sosial dan penghormatan yang bersifat sosial (lihat kecenderungan variabel $A$ dan $B$ ).

Sub -variabel 2 yang juga mendapatkan nilai indeks sangat tinggi tentang peran tokoh agama. Tampak dengan jelas, para responden memberi kepercayaan penuh kepada tokoh agama sebagai leading sector terciptanya perdamaian sosial dan kerukunan antar umat beragama.

Sub variabel yang paling rendah adalah yang terakhir (8). Sub-variabel ini mendapatkan nilai mendekati ambang batas indeks rendah $(2,50)$. Ini menunjukkan konsistensi persepsi responden dari awal. Mereka agak hati-hati memberi afirmasi terhadap hal-hal yang bersifat "internum" agama.
C.5. Indeks KUB berdasarkan variabel keempat (peran pemerintah)

Tabel 5; Indeks kerukunan berdasarkan subvariabel pada variabel keempat

\begin{tabular}{|c|c|c|c|}
\hline No & Subvariabel & Indeks & Kategori \\
\hline 1 & $\begin{array}{l}\text { Pembangunan Rumah Ibadah } \\
\text { Sebaiknya mendapatkan jaminan } \\
\text { dari pemerintah }\end{array}$ & 3,23 & Tinggi \\
\hline 2 & $\begin{array}{l}\text { Keterlibatan pemerintah } \\
\text { mempercepat proses penyelesaian } \\
\text { konflik }\end{array}$ & 3,22 & Tinggi \\
\hline 3 & $\begin{array}{l}\text { Pemerintah sebaiknya melindungi } \\
\text { kelompok yang mendapatkan } \\
\text { tindakan kekerasan dari kelompok } \\
\text { lain }\end{array}$ & 3,30 & $\begin{array}{l}\text { Sangat } \\
\text { Tinggi }\end{array}$ \\
\hline 4 & $\begin{array}{l}\text { Pemerintah seharusnya menindak } \\
\text { tegas ormas yang melakukan } \\
\text { tindakan kekerasan }\end{array}$ & 3,24 & Tinggi \\
\hline 5 & $\begin{array}{l}\text { Pemerintah harus memfasilitasi } \\
\text { dialog antar kelompok agama } \\
\text { yang berbeda pandangan }\end{array}$ & 3,04 & Tinggi \\
\hline 6 & $\begin{array}{l}\text { Pemerintah tidak boleh } \\
\text { mencampuri praktik ibadah } \\
\text { agama tertentu }\end{array}$ & 2,32 & Rendah \\
\hline 7 & $\begin{array}{l}\text { Pemerintah sebaiknya bekerja } \\
\text { sama dengan tokoh agama untuk } \\
\text { meningkatkan KUB }\end{array}$ & 3,31 & $\begin{array}{l}\text { Sangat } \\
\text { Tinggi }\end{array}$ \\
\hline 8 & $\begin{array}{l}\text { Pemerintah sebaiknya } \\
\text { memrogramkan kurikulum KUB } \\
\text { sebagai muatan lokal }\end{array}$ & 3,16 & Tinggi \\
\hline & Indeks Keseluruhan & 3,10 & Tinggi \\
\hline
\end{tabular}

Sumber data: angket yang diolah.

Data pada tabel di atas menunjukkan bahwa seluruh sub variabel mendapatkan nilai tinggi kecuali sub-variabel 6 . Sub variabel ini 'hanya' mendapatkan nilai 2,32. Mayoritas responden menginginkan pemerintah ikut campur dalam urusan agama masyarakat. Idealnya pemerintah tidak boleh terlibat dalam urusan ibadah agama tertentu. Ini negara kebangsaan bukan negara agama. Tetapi responden cenderung melihatnya dalam perspektif perdamaian. Sederhananya begini. Tafsir terhadap perbedaan agama seringkali muncul ke permukaan dalam bentuk konflik. Mulai dari kasus yang ringan seperti perbedaan tafsir terhadap 1 Ramadhan dan Syawal hingga yang berat seperti perbedaan cara pandang terhadap negara dan kenabian. Warga menginginkan pemerintah memberi intervensi terhadap ini. Tentu saja kepentingannya agar perbedaan tafsir itu tidak meledak menjadi rusuh sosial. Dalam konteks hubungan antar umat beragama, konflik 
antar agama adalah tanggungjawab pemerintah. Kisruh pendirian rumah ibadah misalnya harus diselesaikan oleh negara.

\section{Membaca nalar kerukunan masyarakat Kab. Konsel}

Nilai indeks 2, 86 (tinggi) yang ditemukan dalam riset ini melalui rangkaian analisa statistik cukup untuk memberi gambaran kepada kita tentang kondisi kerukunan di Konsel. Bahwa kerukunan antar umat beragama disana sedang berlangsung dengan baik. Tidak salah apabila orang Konsel percaya dan bangga dengan kerukunan di kampung mereka (sebagaimana yang disebutkan di bagian awal tulisan ini). Hasil penelitian ini dan tidak adanya konflik sosial yang pernah terjadi bisa menjadi legitimasinya.

Warga percaya nilai adat, tokoh adat, tokoh agama dan pemerintah menjadi titik pijak yang penting untuk membangun kerukunan antar umat beragama (lihat juga Arsalim Arifin dkk, 2013). Nilai indeks untuk dua variabel ini tinggi. Ada beberapa sub variabel yang mendapatkan indeks sangat tinggi (lihat tabel 3 dan 4). Bahkan untuk pemerintah, masyarakat meletakkannya dalam bentuk yang sangat supra power. Masyarakat bahkan "membolehkan" pemerintah ikut campur dalam urusan internal agama demi kerukunan dan stabilitas. Bisa dipahami karena ide dan gagasan pemisahan negara dan masyarakat tidak sepenuhnya selesai di Indonesia. Bentuk relasi negara dan agama mengalami ambivalensi terus menerus. Kehadiran kementerian agama dan MUI (yang merepresentasi negara) adalah bentuk "permanen" campur tangan negara terhadap urusan keagamaan masyarakat Indonesia.

Warga juga percaya adat sebagai katup pengaman yang sangat penting. Kalo sara sebagai simbol adat masih sangat fungsional dalam penyelesaian konflik. Gelang yang terbuat dari rotan itu dipercaya sangat sakral. Siapa yang melanggar akan kena akibatnya. Seorang pedagang durian menceritakan, pernah suatu waktu ada tiga orang yang 'kurang percaya' dengan melangkahi kalo tersebut. Tidak lama kemudian, ketiganya meninggal dunia.

Penyelesaian konflik antar individu berbasis adat (Tolaki) masih sangat jamak ditemui. Misalnya kasus seorang lelaki (pendatang) yang ketahuan 'berduaan' dengan seorang gadis Tolaki. Semuanya bisa selesai dengan cara damai melalui pendekatan adat. Tentu ada denda (5 juta) yang harus dibayarkan sang lelaki. Denda itu membebaskan sang lelaki dari "kewajiban" menikahinya. Tidak ada amarah yang berlebihan dari keluarga perempuan karena adat sudah turun tangan. Semua itu dianggap selesai.

Cara pengelolaan konflik biasanya berbasis korban (jika terjadi kasus beda suku). Asal usul si korban yang menjadi asumsi penyelesaian. Jika korban berasal dari suku Bali misalnya sedangkan pelakunya orang Tolaki maka proses penyelesaiannya diserahkan kepada "penyelesaian" konflik ala tradisi orang Bali. Begitu pula sebaliknya. Dengan pola ini, ada banyak kasus yang bisa diselesaikan secara adat. Tidak perlu sampai ke polisi dan tidak perlu meledak menjadi konflik komunal.

Selain menjadi mekanisme penyelesaian konflik, lokalitas menjadi salah satu modal sosial untuk menjalin harmonisasi antar warga. Misalnya tradisi malulo. Tradisi yang merupakan khas orang Tolaki saat ini telah menjadi milik bersama. Orang Bali, Jawa, dan Bugis yang ada disana sudah sangat fasih dan menyenangi kegiatan adat ini. Tidak ada rasa canggung budaya ketika tradisi ini dimulai

Di luar itu, orang Tolaki memang dikenal ramah dan adaptif. Mereka mudah menerima kehadiran orang luar dengan sangat akrab. Hal ini menyebabkan kehadiran orang Bali, Jawa, dan Bugis tidak mendapatkan tantangan apa-apa. Tidak mengherankan apabila fenomena kawin mawin antar etnik jamak terjadi. Tidak mengherankan pula bila lebih dari separuh responden penelitian ini mengaku punya kerabat yang beda agama (lihat data jalinan kekerabatan antar agama). Ada aturan yang tidak tertulis dalam masyarakat Konsel, kalau perempuan yang ikut agama suaminya. Namun, saya menemukan ada satu orang pasangan (Flores dan Tolaki) yang tetap mempertahankan agamanya masing-masing selama puluhan tahun mereka menikah.

Kalaupun ada gugatan, biasanya berbasis pada perebutan resources tanah. Ketika sumber daya tanah sudah mulai menipis. Mulai muncul gugatan dari penduduk lokal terhadap klaim tanah orang transmigran. Ada yang selesai secara adat. Ada yang melalui persidangan. Ada pula yang berakhir dengan konflik individual (kasus perkelahian orang Bali dan Tolaki di Konawe tahun 2000. Satu orang Bali meninggal dan satu orang Konawe meninggal. Tetapi, konflik individual ini tidak meledak).

Selain itu ada resources sosial yang juga turut berperan dalam pencegahan konflik yaitu FKPM (Forum Kerja Sama Polisi dan Masyarakat). Forum 
ini terbentuk di beberapa kecamatan di Kab. Konsel. Seluruh perwakilan etnik duduk dalam forum ini. Tokoh etnik ini berperan untuk meredam setiap kemungkinan terjadinya konflik antar warga yang berbeda suku dan agama.

Model kerukunan warga Konsel adalah tipikal kerukunan masyarakat Indonesia. Model inklusif, bukan pluralis (Sukidi, 2001; Franz M. Suseno, 2005). Mereka welcome terhadap hubungan sosial tetapi hati-hati terhadap hubungan yang bernuansa internal agama. Ini jelas terlihat pada penelitian ini. Persepsi responden cenderung menurun ketika pertanyaan diarahkan kepada hal-hal yang bersifat keagamaan, misalnya rumah ibadah, doa bersama, donasi terhadap agama lain, menghadiri acara keagamaan dan mengundang. Bagi sebagian responden, hal ini masih 'tabu' untuk dirayakan. Dan, data riset ini menunjukkan bahwa responden yang 'tabu' untuk merayakan 'religuisitas' secara terbuka mayoritas berasal dari responden beragama Islam (lihat tabel variabel 1 dan 2).

Apa itu berarti ada 'sesuatu' dalam ajaran Islam yang melarang dialog antar iman? Melarang doa bersama? Melarang memberi bantuan kepada acara keagamaan orang lain? Apa doktrin lakum dinukum waliya din begitu kuat mengakar dalam nalar masyarakat muslim? Doktrin yang membatasi masyarakat Islam untuk berhubungan secara terbuka dalam konteks sosioreligius. Apakah karena orang Islam tidak ingin ikut natal karena ketakutan akidahnya tercemar? Tentu tidak mudah menjawabnya.

Saya memandang fenomena itu dengan dua cara. Pertama, nilai dan ajaran agama yang dianut oleh warga Konsel selama ini tidak menjadi mengajarkan permusuhan. Tidak menjadi sumber ancaman konflik. Nilai Islam yang dipahami oleh responden berbasis pada persahabatan dan perdamaian (lihat variabel 3 sub-variabel 1). Begitu pula dengan responden beragama Kristen, Katolik, dan Hindu. Ajaran kasih dan tatwam asih menjadi salah satu basis agama mereka. Dengan pola ajaran yang damai itu, agama tidak perlu lagi dipertemukan dalam konteks sosial. Tidak perlu dialog antar agama karena agama telah berfungsi sebagai agen perdamaian di masing-masing kelompok. Tentu berbeda apabila warga memahami ajaran Islam misalnya mengajarkan permusuhan dan diskriminasi terhadap umat lain. Dialog antar iman dan agama menjadi sangat penting untuk dilakukan.
Kedua, adanya sindrom mayoritas. Keengganan sebagian besar responden beragama Islam jika ada kelompok lain membangun gereja dan rumah ibadah lainnya bersumber dari kalkulasi jumlah. Mereka menganggap tidak boleh mendirikan rumah ibadah kalau jumlah mereka tidak cukup banyak. Orang Islam sebagai representasi mayoritas merasa 'punya' hak untuk menentukan boleh tidaknya rumah ibadah umat lain berdiri. Tentu saja sindrom mayoritas ini tidak hanya berlaku untuk hubungan antar umat beragama tetapi juga internal umat Islam. Seorang informan (tokoh adat) pernah mengusir seorang dari kelompok Islam tertentu yang melarang praktik pernikahan masyarakat yang dianggap keluar dari syariat Islam.

Kelompok minoritas memiliki peluang lebih untuk active seeking of understanding across line of difference (dalam bahasa Diana L Eck), pencarian pemahaman yang aktif terhadap perbedaan. Kelompok minoritas (sebagaimana yang diperlihatkan data statistik) lebih terbuka dan welcome terhadap kepelbagaian bahkan meski dalam konteks agama sekalipun. Ini sebagai bagian dari proses adaptasi dengan lingkungan. Orang Hindu di Konsel (kecuali di Desa Jati Bali) misalnya tidak terlalu risau ketika 'nyepi' mereka tidak sesepi di Bali. Mereka menikmatinya dengan memberi tafsir baru terhadap makna nyepi. Mereka sadar tidak mungkin meminta privelege nyepi karena jumlah yang sedikit. Mereka harus aktif mencari pemahaman terhadap perbedaan. Ketika nyepi selesai, mereka bersedia mengundang 'orang-orang yang mengganggu nyepi' itu untuk datang makan bersama. Tentu saja ini berbeda ketika dengan umat Hindu di Bali. Seluruh kelompok non Hindu harus tunduk pada aturan nyepi, tak terkecuali.

Sindrom mayoritas ini adalah fenomena umum di seluruh dunia. Kelompok manapun yang 'kecil' akan kesulitan untuk mengekspresikan gagasannya secara bebas sebagaimana kaum mayoritas. Bagi saya, terlalu naif untuk mengatakan kalau akidah adalah alasan utama masyarakat untuk enggan 'membuka' ruang untuk saling mempelajari satu sama lain. Mungkin saja iya, tetapi kekakuan itu hanya karena memang tidak diajarkan dan tidak dibiasakan. Pengelolaan agama memang berbasis pada keberjarakan, bukan intimitas. Orang-orang yang berada di level elit agama pun agak enggan mendialogkan agama karena menganggap tidak perlu. Kita masih ingat fatwa haram pluralisme dan selamat ucapan selamat natal oleh MUI tahun 2006. 
Padahal, suka atau tidak saling mempelajari menjadi penting dalam masyarakat yang plural. Keharaman babi bagi umat Islam penting untuk diketahui oleh agama lain. Kepentingannya tentu bukan melaksanakan ajaran Islam itu bagi mereka atau mendebat itu, tetapi untuk pengaturan sosial. Bagaimanapun juga, suatu saat mereka harus menjamu orang-orang Islam di acara kawinan mereka. Begitu pula, umat Islam harus tahu kalau sebagian orang Hindu 'menghormati' sapi misalnya. Kepentingannya, kalau menjamu orang Hindu tidak boleh menghidangkan daging sapi.

\section{PENUTUP}

\section{Kesimpulan}

Temuan penelitian menunjukkan beberapa hal:

Indeks kerukunan antar umat beragama di Kab. Konsel berada pada indeks tinggi. Ini berarti kerukunan antar umat sedang berada dalam kondisi yang baik. Penerimaan dan penghargaan terhadap sesama warga relatif tinggi. Hal ini ditunjukkan dengan sikap terbuka dalam konteks hubungan sosial. Bahkan, untuk responden yang berasal dari kelompok agama minoritas menampakkan keterbukaan dalam hal keagamaan. Sedangkan untuk kelompok mayoritas mengalami hambatan psikologis untuk mengartikulasi pergaulan yang terbuka dalam konteks keagamaan. Hambatan ini tidak lantas berarti buruk bagi pola kerukunan. Keengganan untuk berdialog dalam konteks agama adalah bagian dari strategi peace building.

Faktor agama, usia, dan pengalaman interaksi tampaknya mempengaruhi kualitas kerukunan antar umat beragama. Kelompok agama mayoritas mengalami hambatan dalam hal merayakan pergaulan dalam konteks keagamaan meski secara sosial tidak bermasalah. Kelompok responden yang berusia matang menunjukkan sikap yang lebih terbuka. Begitu pula dengan pengalaman interaksi, semakin tinggi interaksinya maka peluang semakin rukun lebih besar.

Faktor adat dan karakter orang Tolaki yang terbuka menjadi salah satu katup pengaman yang penting dalam konteks pembangunan kerukunan. Hukum adat sejauh ini menjadi elemen penting yang dapat menyelesaikan konflik antar individu.

\section{UCAPAN TERIMA KASIH}

Penulis menyampaikan terima kasih kepada redaksi jurnal Al-Qalam yang telah memuat tulisan ini. Ucapan terima kasih juga penulis sampaikan kepada seluruh informan yang telah bersedia mengisi angket penelitian pada saat penelitian ini di adakan,ucapakan yang sama kami haturkan kepada bapak/ibu, sahabat-sahabat, dan lembaga terkait yang telah membantu peneliti selama di lapangan, tulisan ini diterbitkan berkat bantuan dari berbagai pihak, semoga tulisan ini bernilai dan bermanfaat bagi para pembaca.

\section{DAFTAR PUSTAKA}

Al Qurtuby, Sumanto. "Pluralisme, Dialog, dan Peace Building Berbasis Agama di Indonesia" dalam Elza Peldi Taher (ed). 2009. Merayakan Kebebasan Beragama. ICRP: Jakarta

Arifin, Arsalim. Jumwal Shaleh, Rustam. 2013. Meniti Langkah Menuai Kerja; Refleksi Kemajuan Pembangunan 10 Tahun Konawe Selatan.

Deka, Anita. 2008. Manado Monumen Pluralisme Agama. http://anitadeka.wordpress.com.

Eck, Diana L. 2003. Encountering God: A Spritual Journey from Bozeman to Benaras, MA: Beacon Press.

Editorial Media Indonesia. 2014. www. metrotvnews.com.

Hamdan. 2008. Kerukunan Umat Beragama. http://www.win2pdf.com

Idham. 2011. Konflik ATM. Pascasarjana Universitas Negeri Makassar (disertasi).

Laporan Tahunan Tim Wahid Isntitute tentang Kekerasan atas nama agama di Indonesia, 2008.

Susanto, Trisno. 2010. Melampaui Toleransi. www. kompas.co.id

Sukidi. 2001. Teologi Inklusif Cak Nur. Kompas : Jakarta

Suseno, Frans Magnis. 2005. Pluralisme dalam Sengketa. Makalah disampaikan dalam seminar Tafsir Aktual atas Pluralisme. 12 Oktober 2005.

Tim Peneliti Litbang Agama Makassar. 2009-2013. Potret Kerukunan Umat Beragama di Sulsel, Suteng, Sulut, Kaltim, Gorontalo dan Sulbar. Balai Litbang Agama Makassar.

Beragama di Indonesia Timur.

Walzer, Michael. 1997. On Toleration. Yale University Press: New Haven and London.

Wanggai, Toni Victor. 2009. Rekonstruksi Sejarah Umat Islam di Tanah Papua. Jakarta: Badan Litbang dan Diklat Departemen Agama RI. 